\title{
OBSERVATIONS ON THE INHIBITION OF SULFONAMIDE ACTION BY PARA-AMINOBENZOIC ACID
}

\author{
By ELIAS STRAUSS, FRANCIS C. LOWELL, AND MAXWELL FINLAND \\ (From the Thorndike Memorial Laboratory, Second and Fourth Medical Services (Harvard), \\ Boston City Hospital, and the Department of Medicine, Harvard Medical School, Boston)
}

(Received for publication October 23, 1940)

Considerable interest has been aroused recently in the investigation of substances which inhibit the action of the sulfonamide drugs. Lockwood (1) showed that peptones inhibit the action of sulfanilamide on streptococci. Stamp (2) isolated certain fractions of streptococci, and Green (3) isolated fractions of brucella, which have similar activity with respect to the corresponding organisms. West and Coburn (4) showed that under certain conditions coenzymes inhibit the action of sulfapyridine on staphylococci. MacLeod (5) found that the action of sulfapyridine on the colon bacillus in a synthetic medium can be nullified by extracts of certain animal tissues. Woods (6) extracted fractions of yeast which were capable of overcoming the bacteriostatic action of sulfanilamide on streptococci and on colon bacilli. From an analysis of the properties of the active extracts he was led to test a series of known chemical compounds and found that para-aminobenzoic acid had marked inhibitory properties in vitro. Selbie (7) supplemented this work by demonstrating that mice infected with streptococci could not be saved by sulfanilamide if para-aminobenzoic acid were administered at the same time. The reports of the two last named authors and the discussion of their work by Fildes (8) led us to undertake studies of some of the properties of para-aminobenzoic acid in vitro and in human subjects. In this paper are reported the results of observations on the following aspects of these studies: (1) the quantitative relationship between the bacteriostatic effect of sulfonamides on the pneumococcus and the inhibition of this effect by para-aminobenzoic acid; (2) the stages of the action of sulfapyridine on the pneumococcus during which inhibition by para-aminobenzoic acid is effective; (3) a consideration of the absorption and excretion of para-aminobenzoic acid and its chemical determination in blood and urine; (4) a comparison of the activity of the urine of human subjects following ingestion of para-aminobenzoic acid with the activity of this drug when added in vitro to normal urine (the bacteriostatic effect of sulfathiazole on the colon bacillus was utilized for this purpose) ; (5) a study of the effect of oral administration of para-aminobenzoic acid on the bactericidal power of the blood of subjects receiving sulfonamides; and (6) the effect of paraaminobenzoic acid on rashes and fever due to sulfonamide toxicity.

Quantitative relationship between the concentration of sulfonamides and the inhibitory concentration of para-aminobenzoic acid

The medium used in this and in the following experiment was beef infusion broth containing 0.05 per cent dextrose and 1 per cent bactopeptone (Difco), to which was added 1 per cent defibrinated rabbit blood. Previous studies have demonstrated that in this medium sulfapyridine and sulfathiazole have definite bactericidal action on inocula of pneumococci up to several thousand per milliliter. The bactericidal action of sulfapyridine on pneumococci in this medium is about the same as in defibrinated blood (9). A stock type III pneumococcus (9) was used in this and in subsequent experiments. The virulence of this strain was maintained by mouse passage at weekly intervals. Both the para-aminobenzoic acid 1 and the sulfonamide drugs ${ }^{2}$ (sulfanilamide, sulfapyridine and sulfathiazole) were dissolved in plain broth, sterilized by heating to $100^{\circ} \mathrm{C}$. for 30 minutes, and made up in appropriate concentrations by dilution with broth. The pneumococci were grown in blood broth for 10 to 12 hours, diluted in plain broth, and $0.1 \mathrm{ml}$. of the appropriate dilution was added to $10 \mathrm{ml}$. amounts of the medium containing the test drugs to make a final concentration of about 50 viable diplococci per milliliter. The tubes were incubated at $37^{\circ} \mathrm{C}$. and read at 24 and 48 hours for the presence of visible cloudiness indicating growth.

The results are charted in Figure 1. Within the range studied there was a roughly linear relationship between the concentrations of sul-

1 Chemical grade, obtained from Eastman Kodak Company.

2 Furnished by Lederle Laboratories, Inc. 


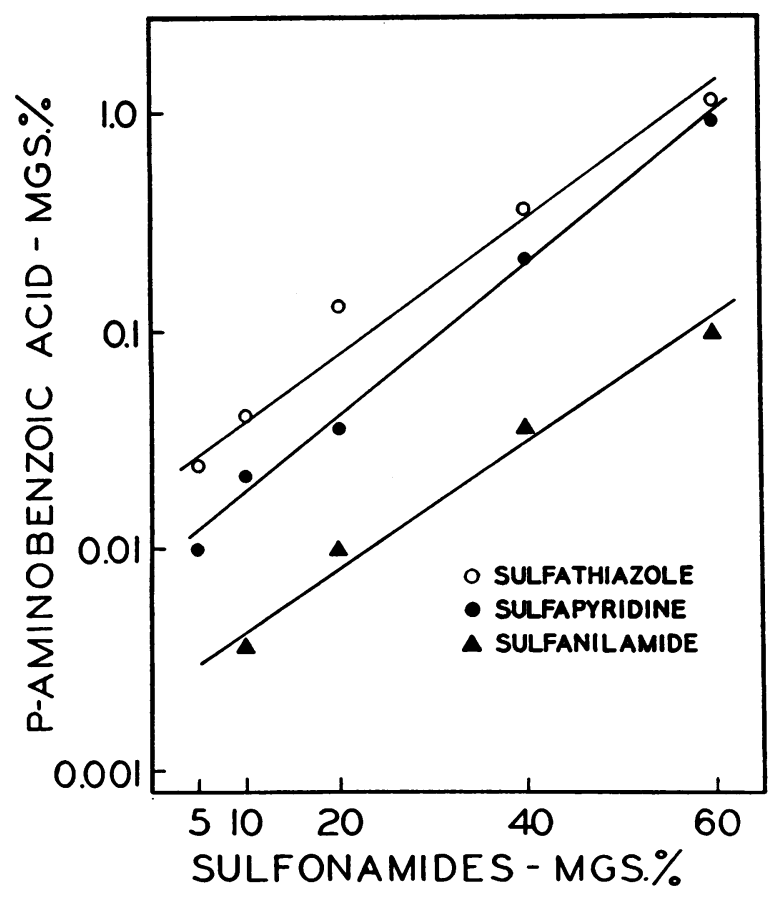

Fig. 1. Minimum Concentrations of p-Aminobenzorc Acid Required to Inhibit the Bacteriostatic Action of Various Concentrations of Three SulfoNAMIDE DRUGS

Semi-logarithmic scale.

fonamides and the minimum concentrations of para-aminobenzoic acid required to inhibit their bacteriostatic action. The inhibitory effect of para-aminobenzoic acid was most marked against sulfanilamide, less against sulfapyridine, and least against sulfathiazole. For example, the bacteriostatic action of $10 \mathrm{mgm}$. per cent of sulfathiazole under these conditions was inhibited by $0.04 \mathrm{mgm}$. per cent of $p$-aminobenzoic acid, whereas the action of similar concentrations of sulfapyridine and sulfanilamide was inhibited by 0.02 and 0.004 mgm. per cent, respectively, of para-aminobenzoic acid. These results can, of course, be interpreted in terms of the growth-stimulating effect of the various concentrations of the latter drug and the greater power of sulfathiazole to overcome this effect. Such an explanation was offered by Lockwood for the inhibitory action of peptone (1). The next experiment suggests that this interpretation is probably not justified.
The stages of sulfapyridine action during which para-aminobenzoic acid inhibition is effective

It was shown in the preceding experiment that 1.0 mgm. per cent of $p$-aminobenzoic acid inhibited the action of sulfapyridine in concentrations up to $60 \mathrm{mgm}$. per cent. In the present experiment a number of identical tubes, each containing $10 \mathrm{mgm}$. of sulfapyridine per 100 milliliters of blood broth, were inoculated with 100 type III pneumococci per milliliter. Para-aminobenzoic acid sufficient to make a final concentration of $1.0 \mathrm{mgm}$. per cent was added to one tube at the beginning of the experiment. All the tubes were then incubated at $37^{\circ} \mathrm{C}$. and blood agar pour plates were made at frequent intervals. Drugfree broth was used to make the proper dilutions of the explants. Two hours after the beginning of the experiment $1.0 \mathrm{mgm}$. per cent of $p$-aminobenzoic acid was added to a second tube. In like manner, equal amounts of this drug were added at 4, 8, 12,16, 20 and 24 hours to the remaining tubes in succession. One tube, containing neither sulfapyridine nor $p$-aminobenzoic acid, and another, containing $10 \mathrm{mgm}$. per cent of sulfapyridine and no $p$-aminobenzoic acid, served as controls. Blood agar pour plate counts were made at frequent intervals.

The results are charted in Figure 2. The typical growth curve from a small inoculum of pneumococci in sulfapyridine broth is shown. There is an initial lag phase, a period of logarithmic increase, and then a phase of decline and death of the bacterial population (10). When p-aminobenzoic acid was added either initially, or during the lag phase or the phase of logarithmic increase, the resulting growth curve in each instance was the same as the normal control and there was no evidence of any sulfapyridine effect. When $p$ aminobenzoic acid was added during the static or declining phase of growth, however, there was a short lag period, following which the organisms began to grow rapidly again. It is evident that $p$-aminobenzoic acid can revive a culture in the presence of sulfapyridine at any stage in the growth curve as long as there are any viable organisms. In this case, at 20 hours there were only two diplococci per milliliter before the addition of $p$-aminobenzoic acid. The addition of the latter drug at 24 hours resulted in no growth, confirming the complete bactericidal action of the sulfapyridine at that time. The control curve of growth when neither sulfapyridine nor $p$-aminobenzoic acid was used was identical with the curve obtained with the latter drug alone. Under the 


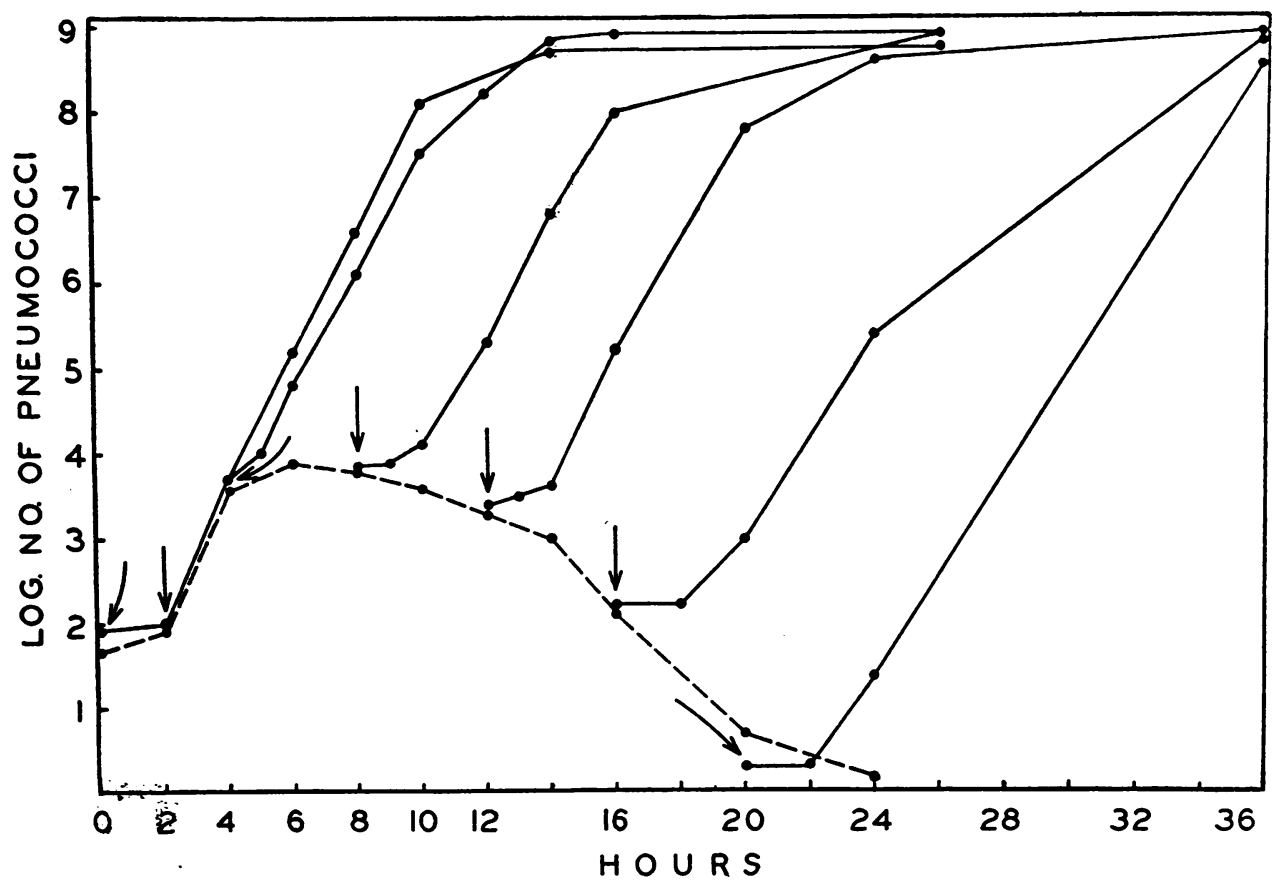

Fig. 2. Effect of Addition of 1.0 Mgm. Per Cent p-Aminobenzoic Acid to the Growth Curve of Stock Type III Pneumococcus in Blood Broth Containing 10 Mgm. Per Cent SUlFAPYRIDINE

Dotted line represents control curves of growth in sulfapyridine before addition of $p$-aminobenzoic acid, and solid lines represent the subsequent growth after addition of $p$-aminobenzoic acid at the various times indicated by the arrows. The curves representing growth when $p$ aminobenzoic acid was added at the beginning of the experiment and 2 hours later, and the control curve of growth in broth without the addition of $p$-aminobenzoic acid are all superimposed. The control sulfapyridine cultures were sterile at 24 hours and remained so even when $p$-aminobenzoic acid was added at that time.

conditions of the experiment, therefore, no additional growth-stimulating effect of $p$-aminobenzoic acid was apparent.

\section{Chemical determination, absorption, excretion and distribution of para-aminobenzoic acid ${ }^{3}$}

Para-aminobenzoic acid, being a primary arylamine, couples with $n$-( 1 naphthyl) ethylenediamine dihydrochloride, producing a red color. It can therefore be detected in body fluids by Bratton and Marshall's method for sulfanilamide (11). However, when both $p$-aminobenzoic acid and a sulfonamide compound are present in blood or urine, it is impossible to estimate the quantity of each by this method.

Para-aminobenzoic acid is readily absorbed fol-

3 We are indebted to Dr. F. H. L. Taylor for his advice and assistance in these studies.
TABLE I

Blood levels of p-aminobenzoic acid in milligrams per $100 \mathrm{ml}$. following single oral doses

\begin{tabular}{|c|c|c|c|c|c|c|c|c|c|c|c|c|c|}
\hline \multirow{3}{*}{$\underset{\text { joct }}{\text { Sub- }}$} & \multirow{3}{*}{ Dose } & \multicolumn{12}{|c|}{ Hours after administration } \\
\hline & & \multicolumn{2}{|c|}{1 hour } & \multicolumn{2}{|c|}{2 hours } & \multicolumn{2}{|c|}{3 hours } & \multicolumn{2}{|c|}{4 hours } & \multicolumn{2}{|c|}{5 hours } & \multicolumn{2}{|c|}{6 hours } \\
\hline & & F. & T. & F. & T. & F. & T. & F. & T. & F. & T. & F. & T. \\
\hline $\begin{array}{l}\text { M.C. } \\
\text { A.R. } \\
\text { T.L. } \\
\text { L. M. } \\
\text { J.E. }\end{array}$ & \begin{tabular}{|c|} 
grams \\
1.0 \\
2.0 \\
4.0 \\
4.0 \\
4.0 \\
4.0
\end{tabular} & $\begin{array}{l}\text { S.T. } \\
1.5 \\
3.0 \\
6.1 \\
2.6\end{array}$ & $\begin{array}{l}0.8 \\
2.2 \\
3.5 \\
6.8 \\
3.6\end{array}$ & $\begin{array}{l}0 \\
\text { S.T. } \\
4.0 \\
5.0 \\
3.8 \\
2.5\end{array}$ & \begin{tabular}{|l|} 
S. T. \\
15.1 \\
6.1 \\
5.7 \\
4.8 \\
\end{tabular} & $\begin{array}{l}2.4 \\
2.6 \\
3.3\end{array}$ & $\begin{array}{l}3.7 \\
3.9 \\
5.4\end{array}$ & $\begin{array}{l}\mathbf{0} \\
\mathbf{0}\end{array}$ & s. T. & $\begin{array}{c}0 \\
\text { o } \\
\text { s. T. } \\
\text { S. T. } \\
0.4\end{array}$ & \begin{tabular}{c|}
0 \\
0 \\
1.0 \\
1.1 \\
2.2
\end{tabular} & $\begin{array}{c}0 \\
0 \\
\text { S. T. }\end{array}$ & $\begin{array}{c}0 \\
0 \\
0.9\end{array}$ \\
\hline
\end{tabular}

S. T. = slight trace (less than $0.1 \mathrm{mgm}$. per $100 \mathrm{ml}$.).

$F$. = concentration of free $p$-aminobenzoic acid in milligrams per $100 \mathrm{ml}$., as determined by the method of Bratton and Marshall for sulfanilamide (11).

$T$. = total concentration of $p$-aminobenzoic acid in milligrams per $100 \mathrm{ml}$., as determined by the method of Bratton and Marshall for sulfanilamide (11). 
lowing ingestion of from 1 to 4 grams (Table I). Maximum blood levels are reached in 1 to 2 hours. Conjugation of the drug apparently begins early and progresses rapidly. Four hours after doses of 1 or 2 grams the compound is no longer detected in the blood. After single 4-gram doses, small quantities are still present in the blood at 6 hours.

Urinary excretion is rapid and largely completed in 12 hours (Table II). About two-thirds of the drug is excreted in the "free" form. When determined as "total" drug (after acid hydrolysis), $p$-aminobenzoic acid is apparently completely recovered in the urine in 12 hours.

TABLE II

Urinary excretion of p-aminobensoic acid following single oral doses

\begin{tabular}{|c|c|c|c|c|c|c|c|c|c|}
\hline \multirow[t]{2}{*}{ Sub- } & \multirow[t]{2}{*}{ Dose } & \multirow{2}{*}{$\begin{array}{c}\text { Hours } \\
\text { after } \\
\text { admin- } \\
\text { istra- } \\
\text { tion }\end{array}$} & \multirow[t]{2}{*}{$\begin{array}{l}\text { Urine } \\
\text { vol- } \\
\text { ume }\end{array}$} & \multirow[t]{2}{*}{ F. } & \multirow[t]{2}{*}{ T. } & \multicolumn{2}{|c|}{$\begin{array}{c}\text { Total } \\
\text { excreted } \\
\text { (cumulative) }\end{array}$} & \multicolumn{2}{|c|}{$\begin{array}{l}\text { Per cent of } \\
\text { adminis- } \\
\text { tered drug } \\
\text { excreted } \\
\text { (cumula- } \\
\text { tive) }\end{array}$} \\
\hline & & & & & & F. & T. & F. & T. \\
\hline & grams & & $m l$. & $\begin{array}{c}\text { mgm. } \\
100\end{array}$ & $\begin{array}{l}\text { per } \\
\text { ml. }\end{array}$ & $m g m$. & mgm. & $\begin{array}{l}\text { per } \\
\text { cent }\end{array}$ & $\begin{array}{l}\text { per } \\
\text { cent }\end{array}$ \\
\hline M. C. & 1.0 & $\begin{array}{l}0-5 \\
5-11\end{array}$ & $\begin{array}{l}270 \\
700\end{array}$ & $\begin{array}{l}85 \\
0.9\end{array}$ & $\begin{array}{r}232 \\
5.0\end{array}$ & $\begin{array}{l}230 \\
236\end{array}$ & $\begin{array}{l}626 \\
661\end{array}$ & $\begin{array}{l}23 \\
24\end{array}$ & $\begin{array}{l}63 \\
66\end{array}$ \\
\hline A. R. & 2.0 & $\begin{array}{l}0-5 \\
5-11\end{array}$ & $\begin{array}{l}730 \\
390\end{array}$ & $\begin{array}{r}184 \\
20\end{array}$ & $\begin{array}{r}274 \\
24\end{array}$ & $\begin{array}{l}1340 \\
1417\end{array}$ & $\begin{array}{l}2003 \\
2097\end{array}$ & $\begin{array}{l}68 \\
71\end{array}$ & $\begin{array}{l}100 \\
105\end{array}$ \\
\hline T. L. & 4.0 & $\begin{array}{c}0-3 \\
3-6 \\
6-12 \\
12-24\end{array}$ & $\begin{array}{r}250 \\
360 \\
950 \\
1130\end{array}$ & $\begin{array}{r}581 \\
322 \\
8.2 \\
1.4\end{array}$ & $\begin{array}{r}684 \\
534 \\
47 \\
7.2\end{array}$ & $\begin{array}{l}1453 \\
2612 \\
2690 \\
2705\end{array}$ & $\begin{array}{l}1710 \\
3632 \\
4080 \\
4161\end{array}$ & $\begin{array}{l}36 \\
65 \\
67 \\
68\end{array}$ & $\begin{array}{r}43 \\
91 \\
102 \\
104\end{array}$ \\
\hline P. D. & 4.0 & $\begin{array}{c}0-3 \\
3-6 \\
6-12 \\
12-24\end{array}$ & $\begin{array}{r}340 \\
125 \\
475 \\
1100\end{array}$ & $\begin{array}{r}557 \\
515 \\
24 \\
2.0\end{array}$ & $\begin{array}{r}710 \\
944 \\
90 \\
9.3\end{array}$ & $\begin{array}{l}1892 \\
2535 \\
2650 \\
2672\end{array}$ & $\begin{array}{l}2413 \\
3593 \\
4021 \\
4123\end{array}$ & $\begin{array}{l}47 \\
63 \\
66 \\
67\end{array}$ & $\begin{array}{r}60 \\
89 \\
101 \\
103\end{array}$ \\
\hline
\end{tabular}

$F$. = concentration of free $p$-aminobenzoic acid in milligrams per $100 \mathrm{ml}$., as determined by the method of Bratton and Marshall for sulfanilamide (11).

$T$. = total concentration of $p$-aminobenzoic acid in milligrams per $100 \mathrm{ml}$., as determined by the method of Bratton and Marshall for sulfanilamide (11).

Following absorption, this compound apparently enters the blood cells but is not equally distributed between cells and extracellular fluid. The concentration of $p$-aminobenzoic acid in blood plasma is about three times as great as its concentration in red cells (Table III).
TABLE III

Distribution of p-aminobenzoic acid between blood plasma and red blood cells

\begin{tabular}{|c|c|c|c|c|c|}
\hline \multirow[b]{2}{*}{ Subject } & \multicolumn{5}{|c|}{ Concentration (mgm. per $100 \mathrm{ml}$.) } \\
\hline & $\begin{array}{l}\text { Whole } \\
\text { blood }\end{array}$ & $\underset{\text { (P) }}{\text { Plasma }}$ & $\begin{array}{l}\text { Cells } \\
\text { (C) } \\
\text { (Calcu- } \\
\text { lated) }\end{array}$ & $\mathbf{C} / \mathbf{P}$ & $\begin{array}{c}\text { Hema- } \\
\text { tocrit } \\
\text { (Cor- } \\
\text { rected) }\end{array}$ \\
\hline T. L. & $\begin{array}{ll}\text { Free } & 4.0 \\
\text { Total } & 5.3\end{array}$ & $\begin{array}{c}\text { mgm. per } \\
100 \text { mi. } \\
6.1 \\
7.9\end{array}$ & $\begin{array}{c}\text { mgm. per } \\
100 \text { ml. } \\
1.9 \\
2.7\end{array}$ & $\begin{array}{l}0.31 \\
0.34\end{array}$ & 50.1 \\
\hline P. D.. & $\begin{array}{ll}\text { Free } & 5.0 \\
\text { Total } & 6.1\end{array}$ & $\begin{array}{l}6.3 \\
7.9\end{array}$ & $\begin{array}{l}2.3 \\
2.2\end{array}$ & $\begin{array}{l}0.37 \\
0.28\end{array}$ & 31.7 \\
\hline
\end{tabular}

Blood obtained 2 hours after a single 4.0-gram oral dose.

Inhibition by para-aminobenzoic acid of the bacteriostatic effect of sulfathiazole on the growth

of $B$. coli in human urine. $A$ compari-

son of urine obtained after ingestion

of para-aminobenzoic acid with

urine to which the drug is

added in Vitro

Urine was collected from a normal subject after oral administration of 4.0 grams of $p$-aminobenzoic acid, and the concentration of the compound excreted in the urine was determined colorimetrically. A specimen of drugfree urine was then obtained from another subject and $p$-aminobenzoic acid was added in vitro in an amount calculated to yield the same concentration of "free" drug as was present in the first sample. The two urines were filtered through Berkefeld candles and tested for sterility. They were then diluted with normal sterile urine to make concentrations of "free" $p$-aminobenzoic acid varying from 500 to $0.01 \mathrm{mgm}$. per cent and both series of dilutions were distributed into tubes containing $5 \mathrm{ml}$. each. Sulfathiazole in the form of a solution of the sodium salt in distilled water was added to each of the two series of $p$-aminobenzoic acid-containing tubes of urine. The final concentrations of sulfathiazole ranged from $500 \mathrm{mgm}$. per cent to $50 \mathrm{mgm}$. per cent. Concentrations of sulfathiazole smaller than $50 \mathrm{mgm}$. per cent were not regularly bactericidal and were therefore not used in this experiment. The final $\mathrm{pH}$ of the drugcontaining urines varied from 7.0 to 7.8. A stock culture of $B$. coli communis was grown in broth and diluted in distilled water, and $0.1 \mathrm{ml}$. of the proper dilution, selected so as to make an inoculum of about 1500 viable organisms per milliliter, was added to each tube of urine. Visible clouding after 48 hours' incubation at $37^{\circ} \mathrm{C}$. was used to indicate growth. At the end of 48 hours subcultures on agar were made to confirm the presence or absence of growth. 
TABLE IV

Pneumococcidal activity of defibrinated human blood following administration of sulfonamides and p-aminobenzoic acid

\begin{tabular}{|c|c|c|c|c|c|c|}
\hline \multirow{2}{*}{$\begin{array}{l}\text { Exper- } \\
\text { iment } \\
\text { num- } \\
\text { ber }\end{array}$} & \multirow{2}{*}{$\begin{array}{c}\text { Time of blood samples in relation to } \\
\text { drug administration }\end{array}$} & \multicolumn{2}{|c|}{$\begin{array}{l}\text { Growth } \\
\text { inhibition }\end{array}$} & \multicolumn{2}{|c|}{$\begin{array}{l}\text { Pneumo- } \\
\text { coccidal } \\
\text { action at } \\
48 \text { hours }\end{array}$} & \multirow{2}{*}{ Remarks } \\
\hline & & $\begin{array}{c}24 \\
\text { hours }\end{array}$ & $\begin{array}{c}48 \\
\text { hours }\end{array}$ & $\begin{array}{c}\text { Inocu- } \\
\text { lum }\end{array}$ & Growth & \\
\hline$I$ & $\begin{array}{l}\text { Control (before drugs) } \\
\text { t hour after SP. (SP. level: } F .=10.5, \mathrm{~T} .=10.5 \text { ) } \\
1 \text { hour after } p \text {-ABA. } \\
2 \text { hours after } p-\mathrm{ABA} \text {. } \\
5 \text { hours after } p-\mathrm{ABA} \text {. }\end{array}$ & $\begin{array}{c}\mathbf{0} \\
10^{5} \\
\mathbf{0} \\
\mathbf{0} \\
10^{5}\end{array}$ & $\begin{array}{c}\mathbf{0} \\
10^{5} \\
\mathbf{0} \\
\mathbf{0} \\
10^{5}\end{array}$ & $\begin{array}{l}104 \\
10^{8}\end{array}$ & $\begin{array}{l}35 \\
50\end{array}$ & $\begin{array}{l}\text { Subject E. C. Single dose of } 5.0 \text { grams Na. SP. i.v., } \\
\text { followed in hour by } 2.0 \text { grams p-A BA. p.o. } \\
\text { Stock type III pneumococcus. Tests done immediately } \\
\text { after last blood sample. }\end{array}$ \\
\hline II & $\begin{array}{l}\text { Control (before drugs) } \\
\text { thour after SP. (SP. level: } F .=10.2, T .=10.4 \text { ) } \\
1 \text { hour after } p-A B A \text {. } \\
2 \text { hours after } p-A B A . \\
4 \text { hours after } p-A B A \text {. }\end{array}$ & $\begin{array}{c}0 \\
10^{4} \\
0 \\
10^{2} \\
10^{3}\end{array}$ & $\begin{array}{c}\mathbf{0} \\
10^{3} \\
\mathbf{0} \\
\mathbf{1 0} \\
\mathbf{0}\end{array}$ & $\begin{array}{l}10^{3} \\
10\end{array}$ & $\begin{array}{l}22 \\
\infty\end{array}$ & $\begin{array}{l}\text { Subject J. E. Single dose of } 5.0 \text { grams Na. SP. i.v., fol- } \\
\text { lowed in i hour by } 1.0 \text { gram p-ABA. p.o. } \\
\text { Stock type V pneumococcus. Tests done after incuba- } \\
\text { tion of blood samples at } 56^{\circ} \text { C. for i hour. }\end{array}$ \\
\hline III & $\begin{array}{l}\text { Before first dose of } p \text {-ABA. (ST. level: } \mathrm{F} .=4.9 \text {, } \\
\mathrm{T} .=5.2 \text { ) } \\
1 \text { hour after second dose of } p \text {-ABA. }\end{array}$ & 10 & 104 & & & $\begin{array}{l}\text { Subject S. L. Received ST. } 1.0 \text { gram every } 4 \text { hours. } \\
\text { p-ABA. } 2.0 \text { grams every } 3 \text { hours, begun after fifth } \\
\text { dose of ST.i which was also continued. } \\
\text { Stock type III pneumococcus. Tests done immediately } \\
\text { after last blood sample. }\end{array}$ \\
\hline IV & $\begin{array}{l}\text { Before first dose of p-ABA. (ST. level: F. }=6.3 \text {, } \\
\text { T. }=7.0 \text { ) } \\
1 \text { hour after fifth dose of } p \text {-ABA. }\end{array}$ & 10 & 10 & 10 & $\begin{array}{l}10 \\
0\end{array}$ & $\begin{array}{l}\text { Subject L. C. Received ST. } 1.0 \text { gram every } 4 \text { hours. } \\
\text { On tenth day of ST. therapy received in addition } 1.0 \\
\text { gram p-ABA. every } 2 \text { hours. } \\
\text { Stock type III pneumococcus. Blood samples kept in } \\
\text { icebox for } 72 \text { hours before testing. }\end{array}$ \\
\hline
\end{tabular}

Growth inhibition. Numbers represent the largest inoculum which showed no color change in the blood.

Pneumococcidal action. Listed only when inhibition was noted. Growth refers to number of colonies grown in agar pour plates. Inoculum refers to original number added to the blood. Larger inocula yielded too many colonies to count; smaller ones yielded no growth.

Abbreviations. ST. = sulfathiazole

SP. = sulfapyridine

$\mathrm{Na}$. SP. = sodium sulfapyridine

p-ABA. = p-aminobenzoic acid

i.v. $=$ intravenous

p.o. $=$ oral

F. = concentration of free sulfonamide in mgm. per $100 \mathrm{ml}$.

$\mathrm{T} .=$ concentration of total sulfonamide in $\mathrm{mgm}$. per $100 \mathrm{ml}$.

$\infty=$ innumerable.

This experiment was repeated several times. The general character of the results was similar in each instance and corresponded to the results obtained by Woods (6), who used sulfanilamide and a synthetic medium instead of sulfathiazole and urine, respectively. Quantitatively, however, the results varied widely, as may be expected with a medium as variable as urine. In each experiment there was a marked difference between the activity of $p$-aminobenzoic acid added in vitro and its activity when excreted in the urine. When added in vitro, $0.1 \mathrm{mgm}$. per cent of $p$-aminobenzoic acid usually inhibited the action of $250 \mathrm{mgm}$. per cent or less of sulfathiazole; when excreted in the urine, on the other hand, $10 \mathrm{mgm}$. per cent of $p$-aminobenzoic acid was required to inhibit the action of $100 \mathrm{mgm}$. per cent or less of sulfathiazole. The bactericidal effect of $500 \mathrm{mgm}$. per cent of sulfathiazole could not be overcome even by $500 \mathrm{mgm}$. per cent of $p$-aminobenzoic acid.
However, such high concentrations of $p$-aminobenzoic acid in themselves inhibited growth in control tubes containing no sulfathiazole. While these tests were not entirely satisfactory, they clearly indicated that $p$-aminobenzoic acid is considerably more active when it is added to urine in vitro than when it is excreted in urine following ingestion.

\section{Effect of ingestion of para-aminobenzoic acid on the pneumococcidal activity of the blood of subjects receiving sulfonamides}

Bactericidal tests were carried out on defibrinated blood, as in previous studies (9). In some instances, subjects were selected whose blood was previously shown to lack pneumococcidal power for the pneumococcus strains used. In other instances, blood samples, the pneumococcidal properties of which were unknown, were inactivated before the test by heating at $56^{\circ} \mathrm{C}$. for $1 / 2$ hour, or by storing at icebox temperature for 72 hours so as to eliminate any bactericidal action that might be residing in the fresh blood. The essential details and the results of four separate experiments are shown in Table IV. 
Experiment I. Subject E. C. was a normal adult whose freshly shed blood was shown on previous occasions to be completely devoid of pneumococcidal action for the stock type III pneumococcus. $\mathrm{He}$ was given $\mathbf{5 . 0}$ grams of sodium sulfapyridine intravenously, followed in $1 / 2$ hour by 2.0 grams of $p$-aminobenzoic acid orally. Blood samples were obtained immediately before each of the two drugs were given and also 1, 2 and 5 hours after the $p$-aminobenzoic acid was ingested. All the bloods were then tested for pneumococcidal action on the stock type III pneumococcus.

The control blood again had no pneumococcidal action. Following the intravenous injection of the sodium sulfapyridine, $0.5 \mathrm{ml}$. of this subject's blood inhibited the growth of 100,000 organisms for 48 hours and killed 10,000. The blood samples drawn 1 and 2 hours after the ingestion of the $p$-aminobenzoic acid showed complete loss of the killing power acquired as a result of the administration of sulfapyridine. The last blood, taken after 5 hours, however, again showed marked killing power. It was demonstrated in the previous section ( $c f$. Table II) that $p$-aminobenzoic acid in this dose cannot be detected in the blood 5 hours after its oral administration. On the other hand, effective concentrations of sulfapyridine are still present in the blood for a much longer period following the intravenous injection of 5 grams of this compound (12).

Experiment II. Subject J. E. was another normal adult in whom a preliminary blood sample showed no killing power for type $\mathrm{V}$ pneumococcus. This subject was likewise given 5.0 grams of sodium sulfapyridine intravenously, followed this time by $1.0 \mathrm{gram}$ of $p$-aminobenzoic acid by mouth. Blood samples were taken as before, except that the last blood was taken 4 hours after the $p$-aminobenzoic acid and each sample was heated at $56^{\circ} \mathrm{C}$. for 30 minutes after it was drawn. These pneumococcidal tests were done with the stock type $\mathrm{V}$ strain.

Again the control blood lacked pneumococcidal action. In the first sample obtained after the intravenous administration of the 5.0 grams of sodium sulfapyridine, $0.5 \mathrm{ml}$. of this subject's blood killed 1000 pneumococci. The blood obtained 1 hour after the $p$-aminobenzoic acid ingestion lacked all bactericidal or even bacteriostatic action. The bloods taken after 2 and 4 hours were unable to kill more than 10 pneumococci per milliliter, but showed some bacteriostasis.

Experiments $I I I$ and $I V$. These experiments were carried out with the blood of 2 patients who were receiving sulfathiazole and were also the subjects of studies on the effect of $p$-aminobenzoic acid on toxic reactions. The stock type III pneumococcus was used. Initial bloods taken during the sulfathiazole therapy and before the administration of $p$-aminobenzoic acid showed moderate degrees of pneumococcidal activity consistent with the concentrations of sulfathiazole which these blood samples contained. In both patients, bloods taken after the administration of $p$-aminobenzoic acid lost almost all of this pneumococcidal action. In Subject S. L. (Experiment III) the second blood was obtained 1 hour after two 2-gram doses had been given, and in Subject L. C. the second blood was obtained 1 hour after five doses of 1.0 gram each had been given at 2-hour intervals (Experiment IV).

These experiments demonstrate that after the ingestion and absorption of $p$-aminobenzoic acid the bactericidal and bacteriostatic effect of sulfonamides on the pneumococcus is inhibited in the blood just as it is on addition of $p$-aminobenzoic acid in the test tube.

\section{Attempts to overcome and to prevent sulfonamide fever and rash by the administration of para-aminobenzoic acid}

Fildes (8), on the basis of the studies of Woods and Selbie referred to previously, made the suggestion that $p$-aminobenzoic acid might inhibit not only the bactericidal action of the sulfonamides but also their toxic effects in human tissues. The mechanism by which such toxic effects on body tissues are brought about is not known, and its relation to the mode of action of the drugs on bacteria is, therefore, not clear; nor is the same mechanism necessarily involved even in the different manifestations of toxicity. Drug fevers and rashes were selected for the present study because: (1) they are objective manifestations, (2) they subside fairly promptly on withdrawal of the offending drug and (3) they can usually be reproduced in the same patient, at least with the same drug. It is recognized, however, that these effects sometimes clear up while the drug is being continued.

Patients exhibiting either or both of these signs while under treatment with sulfapyridine or sulfathiazole were maintained on the same dose of 
these drugs and given, in addition, 1 or 2 grams of $p$-aminobenzoic acid by mouth every 2 or 3 hours. The latter amounts were more than sufficient to overcome completely the antibacterial effects of the chemotherapeutic agents in the blood and urine in vitro ( $c f$. Experiments III and IV in Table IV). Nevertheless, neither the fever nor the rash was influenced. When the sulfonamide was discontinued, the toxic signs cleared up in each instance, irrespective of whether the $p$-aminobenzoic acid doses were maintained or stopped.

Some of the patients, after a lapse of a week or longer without any drugs, were subsequently given regular large doses of $p$-aminobenzoic acid first, and later, in addition, were given some of the same sulfonamide drug which had previously produced fever and a rash. There were no untoward effects from the $p$-aminobenzoic acid while it was being taken alone, but the fever and rash regularly recurred within a few hours after the sulfonamide was given, even in spite of the continued administration of the $p$-aminobenzoic acid. Again, the toxic symptoms cleared when the sulfonamides were discontinued, regardless of whether or not the $p$-aminobenzoic acid doses were maintained.

A number of subjects were given $p$-aminobenzoic acid alone in repeated doses for 3 days without any ill effects.

\section{DISCUSSION}

The present observations which concern the inhibition of the action of sulfonamides on bacteria by $p$-aminobenzoic acid are consistent with Fildes' hypothesis (8), which considers substances of this type as "essential metabolites" that are displaced at some stage of bacterial growth by adequate concentrations of sulfonamides. West and Coburn's (4) observations likewise fit into this theory. On the other hand, our studies thus far fail to substantiate the idea that $p$-aminobenzoic acid plays the same rôle in animal cells and that the same mechanism would explain such toxic reactions as the fever and rash that result from therapy in human cases. The possibility that other toxic effects of sulfonamides may be affected by $p$-aminobenzoic acid or by similar chemicals is not excluded.

The results of the present studies suggest some useful laboratory applications for the activity of $p$-aminobenzoic acid. Body fluids, such as blood, urine, and spinal fluids obtained from patients under treatment, frequently contain relatively high concentrations of sulfonamide drugs. When explants are made in nutrient broth or agar plates, enough sulfonamide is sometimes carried over to delay or prevent the growth of organisms that may be present. In such circumstances the addition of $p$-aminobenzoic acid to the nutrient medium will overcome this sulfonamide action and allow full growth of any organisms, provided they are still viable. This should be useful in determining the success of sulfonamide therapy.

Although the fate of $p$-aminobenzoic acid in the body is not clearly known, there can be little doubt that the compound is excreted, at least partly, in altered form. Modifications of the amino and carboxyl groups are most likely to occur. When $p$-aminobenzoic acid is injected into rabbits, about 25 per cent of it is recovered in the urine in the acetylated form (13). The present studies indicate that humans also acetylate this compound. Drug excreted in the urine, when determined colorimetrically by Bratton and Marshall's method, yielded higher "total" than "free" readings, that is, after acid hydrolysis more amino groups were available for diazotization. On the other hand, when solutions of the compound were added in vitro and determined by the same method, the results were the same before and after acid hydrolysis. Woods (6) found that alterations in the structure of $p$-aminobenzoic acid modified its antibacterial activity, so that acetoaminobenzoic acid was only half as active as the original compound. Likewise, alteration of the carboxyl group modified this activity. The conversion of the carboxyl group of $p$-aminobenzoic acid to its amide reduced the activity by one-third. Free carboxyl groups are "detoxified" in the body by conjugation. Quick (14) showed that many of the substituted benzoic acids are excreted as glycuronates. It therefore seems likely that the decreased activity of $p$-aminobenzoic acid after excretion in the urine, as compared with its activity when added to urine, can best be explained as the result of chemical alteration in the body, which probably does not affect the determination of "free" $p$-aminobenzoic acid.

It is of interest that in urine no amount of 
$p$-aminobenzoic acid up to and including $500 \mathrm{mgm}$. per cent inhibited the bactericidal action of 500 mgm. per cent of sulfathiazole. It must be added, however, that $500 \mathrm{mgm}$. per cent of $p$-aminobenzoic acid appears, in itself, to prevent growth of $B$. coli in urine, even in the absence of sulfathiazole. Likewise, sulfathiazole in a concentration of $500 \mathrm{mgm}$. per cent may be toxic to bacteria by some action other than the postulated interference with vital metabolic enzymatic action, namely, by some direct lethal action. This latter supposition suggests a possible use for sulfonamide concentrations of this order in the treatment of empyema and other focal purulent lesions in which sulfonamide therapy has not yet yielded satisfactory results. The failure of therapy in such cases is ascribed partly to the inhibitory effect of the purulent exudate on sulfonamide action. Two points must be considered, however, in this connection: (1) The number of bacteria present in such lesions is generally considerably greater than in our experiments in urine; and (2) there is no evidence at present that the inhibitor present in pus is identical with $p$-aminobenzoic acid or acts in the same manner.

\section{SUMMARY AND CONCLUSIONS}

1. There is a roughly linear relationship between the concentrations of sulfonamides that have bacteriostatic action on pneumococci in blood broth and the minimum concentrations of $p$-aminobenzoic acid which inhibit that action. The inhibitory effect of $p$-aminobenzoic acid is most marked against sulfanilamide, less against sulfapyridine and least against sulfathiazole.

2. The action of sulfapyridine on pneumococci can be nullified at any stage by the addition of $p$-aminobenzoic acid. The resulting growth of pneumococci is then identical with that of a similar number of viable organisms freshly inoculated in the same medium without sulfapyridine.

3. Para-aminobenzoic acid is readily absorbed after oral administration. Maximum blood levels are reached in 1 to 2 hours after ingestion. Excretion is rapid and is practically completed in 12 hours. Some of the compound is present in conjugated form in the blood and urine. The drug is found in greater concentration in the plasma than in the red blood cells.
4. Within certain limits, $p$-aminobenzoic acid inhibits the bacteriostatic effect of sulfathiazole on the growth of $B$. coli in human urine. Urine obtained after ingestion of $p$-aminobenzoic acid is considerably less active in this respect than urine to which the same concentration of drug has been added in vitro.

5. The pneumococcidal action of human blood resulting from the administration of sulfonamide drugs can be overcome by the ingestion of $p$-aminobenzoic acid.

6. Toxic effects of sulfathiazole therapy, as manifested by fever and rash, were neither prevented nor cured by the administration of $p$-aminobenzoic acid in amounts sufficient to nullify the bacteriostatic action of the drug in the blood.

The chemical determinations were carried out by Miss Elizabeth Shaler Smith.

\section{BIBLIOGRAPHY}

1. Lockwood, J. S., Studies on the mechanism of the action of sulfanilamide. III. The effect of sulfanilamide in serum and blood on hemolytic streptococci in vitro. J. Immunol., 1938, 35, 155.

2. Stamp, T. C., Bacteriostatic action of sulphanilamide in vitro; influence of fractions isolated from haemolytic streptococci. Lancet, 1939, 2, 10.

3. Green, H. N., The mode of action of sulphanilamide, with special reference to a bacterial growth-stimulating factor (" $\mathrm{P}$ " factor) obtained from $\mathrm{Br}$. abortus and other bacteria. Brit. J. Exper. Path., 1940, 21, 38.

4. West, R., and Coburn, A. F., The relationship of sulfapyridine, nicotinic acid, and coenzymes to the growth of Staphylococcus aureus. J. Exper. Med., 1940, 72, 91.

5. MacLeod, C. M., The inhibition of the bacteriostatic action of sulfonamide drugs by substances of animal and bacterial origin. J. Exper. Med., 1940, 72, 217.

6. Woods, D. D., The relation of $p$-aminobenzoic acid to the mechanism of the action of sulphanilamide. Brit. J. Exper. Path., 1940, 21, 74.

7. Selbie, F. R., The inhibition of the action of sulphanilamide in mice by $p$-aminobenzoic acid. Brit. J. Exper. Path., 1940, 21, 90.

8. Fildes, $P$., A rational approach to research in chemotherapy. Lancet, 1940, 1, 955.

9a. Spring, W. C., Jr., Lowell, F. C., and Finland, M., Studies on the action of sulfapyridine on pneumococci. J. Clin. Invest., 1940, 19, 163.

b. Lowell, F. C., Strauss, E., and Finland, M., Obser- 
vations on the susceptibility of pneumococci to sulfapyridine, sulfathiazole and sulfamethylthiazole. Ann. Int. Med., 1940, 14, 1001.

10. Lowell, F. C., Strauss, E., and Finland, M., Further studies on the action of sulfapyridine on pneumococci. J. Immunol. (In press.)

11. Bratton, A. C., and Marshall, E. K., Jr., A new coupling component for sulfanilamide determination. J. Biol. Chem., 1939, 128, 537.

12. Taylor, F. H. L., and others, A comparative study of the blood concentrations and urinary excretion of sulfapyridine and sulfanilamide after single doses of sulfapyridine and related compounds administered by various routes. J. Clin. Invest., 1940, 19, 201.

13. Harrow, B., Mazur, A., and Sherwin, C. P., Studies in acetylation. The fate of $p$-aminobenzoic acid in the rabbit. J. Biol. Chem., 1933, 102, 35.

14. Quick, A. J., The relationship between chemical structure and physiological response. I. The conjugation of substituted benzoic acids. J. Biol. Chem., 1932, 96, 83. 